\title{
Self-esteem level of Brazilian teenagers victims of bullying and its relation with the need of orthodontic treatment
}

\author{
Nível da autoestima de adolescentes brasileiros vítimas de bullying e sua relação com a necessidade de tratamento \\ ortodôntico
}

Renata Colturato Joaquim GATTO1

Artênio José Isper GARBIN

José Eduardo CORRENTE²

Cléa Adas Saliba GARBIN ${ }^{1}$

\section{ABSTRACT}

\section{Objective}

The aim of this study was to analyze self-esteem among Brazilian adolescents and also verify possible associations between the variables: the need for orthodontic treatment and bullying.

\section{Methods}

The cross-sectional, population-based epidemiological study consisted of a sample composed of adolescents from 11 to 16 years of age, enrolled in the public school system of a medium-sized municipality in the northwest of the State of São Paulo, Brazil. A dental examination was performed using the Dental Aesthetic Index (DAI) in order to verify the need for orthodontic treatment and a self-administered questionnaire containing the Global Self-Evaluation (GSE) indices to identify the level of self-esteem and Kidscape in order to detect bullying. Data analysis was performed using descriptive statistics, association analysis and multivariate logistic regression.

\section{Results}

A total of 815 adolescents participated in the study. There was a statistically significant association between self-esteem and the variables: sex $(p<.0001)$, willingness to straighten teeth to improve appearance $(p=0.0006)$, bullying victim $(p<.0001)$, frequency of bullying $=0.0111)$ and consequences of bullying ( $p<.0001)$. A significant risk factor for non-white adolescents' very negative self-esteem (OR = 1.914) was present together with bullying victims who had had negative consequences after the episode $(O R=3.343)$.

\section{Conclusion}

There was an association between the self-esteem and bullying variables. Those who reported negative consequences on bullying were three times more likely to present very negative self-esteem, and the chances of non-white adolescents to show negative selfesteem were almost twice as high. There was no statistically significant association between self-esteem and the need for orthodontic treatment.

Indexing terms: Adolescent. Bullying. Health school. Malocclusion. Orthodontics. Self-concept.

\section{RESUMO}

Objetivo

Analisar o nível da autoestima de adolescentes brasileiros e verificar as possíveis associações de desfecho com a necessidade de tratamento ortodôntico e bullying.

\section{Métodos}

Estudo epidemiológico transversal de base populacional. A população foi composta por adolescentes de 11 a 16 anos, matriculados na rede pública de ensino de um município de médio porte do noroeste paulista. Foi realizado um exame bucal utilizando o índice Dental Aesthetic Index (DAl), para verificar a necessidade de tratamento ortodôntico, e um questionário autoaplicável, contendo os índices Global Self-Evaluation (GES), para identificar o nível de autoestima, e o Kidscape, para detecção de bullying. A análise dos dados foi feita utilizando estatística descritiva, análises de associação e regressão logística multivariada.

\section{Resultados}

No total, 815 adolescentes participaram da pesquisa. Houve associação estatisticamente significante entre autoestima e as variáveis: sexo $(p<.0001)$, vontade de corrigir os dentes para melhorar a aparência $(p=0.0006)$, vítima de bullying $(p<.0001)$, frequência com que sofreu bullying $(p=0.0111)$ e consequências do bullying $(p<.0001)$. Apresentaram-se como fator de risco significante para uma autoestima muito negativa a cor da pele não branca $(\mathrm{OR}=1.914)$ e vítimas de bullying que tiveram consequências negativas após o episódio $(\mathrm{OR}=3.343)$.

\section{Conclusão}

Houve associação entre as variáveis autoestima e bullying. Aqueles que relataram consequências negativas sobre o bullying apresentaram chances três vezes maiores de ter autoestima muito negativa, já as chances dos adolescentes com cor da pele não branca foram quase duas vezes maiores. Não houve associação estatisticamente significante entre autoestima e necessidade de tratamento ortodôntico.

Termos de indexação: Adolescente. Bullying. Saúde escolar. Má oclusão. Ortodontia. Autoimagem.

\footnotetext{
${ }^{1}$ Universidade Estadual Paulista Júlio de Mesquita Filho, Faculdade de Odontologia, Programa de Pós-graduação em Odontologia Preventiva e Social. Rua José Bonifácio, 1193, Vila Mendonça, 16015-050, Araçatuba, SP, Brasil. Correspondência para / Correspondence to: RCJ GATTO. E-mail: <renata_colturato@hotmail.com>.

${ }^{2}$ Universidade Estadual Paulista Júlio de Mesquita Filho, Instituto de Biociência, Departamento de Bioestatística. Botucatu, SP, Brasil.
} 


\section{INTRODUCTION}

The different ways of violence expressions affect society as a whole, its different sectors and social levels. The child and the adolescent are more susceptible to violent situations in which they are exposed in the social, family or school environment ${ }^{1}$. The phenomenon known as bullying or bullying among peers or peers in school-age children is considered a subtype of violence. It can be defined as a specific form of aggressive behavior in which the student is repeatedly exposed to negative actions, by one or more students ${ }^{2}$. One of its main characteristics is an imbalance in real or perceived power between the victim and the aggressor. It can be manifested in different forms of aggression: direct (physical and verbal aggression) or indirect (social exclusion, gossip and isolation), causing damage to the victim ${ }^{3}$.

Bullying victims often develop behavioral and emotional problems, such as high levels of stress, decrease or loss of self-esteem, impaired learning and academic performance, anxiety, depression and, in more extreme cases, these problems lead to suicide ${ }^{2,4-5}$.

Self-esteem can be considered the most critical variable which affects the successful insertion of an adolescent into their social relationships. It is said to be an important adolescence mental health indicator ${ }^{6}$, since mechanisms which distort the communication of the adolescents' thoughts and feelings can be developed, imparing their social integration with other adolescents?

Aesthetic beauty standards are strongly related to the level of self-esteem. Malocclusion is considered a deviation from the aesthetic pattern in society, and not a disease in itself, and it can be defined as the anomaly in the development of dental arches, resulting in aesthetic and / or functional problems ${ }^{8-10}$. A disagreeable dental appearance can stigmatize a person, hamper professional achievement, encourage negative stereotypes, and even undermine self-esteem ${ }^{11-13}$.

Although many studies have reported the problem of bullying in schoolchildren, no national study has researched the association of this phenomenon using self-esteem and malocclusion variables. Therefore, the aim of the present study was to analyze the level of selfesteem in adolescents of the public school system as well as to verify the possible associations of orthodontic treatment need and bullying.

\section{METHODS}

\section{Study design}

This is a cross-sectional epidemiological study carried out with adolescents of both sexes, enrolled in public schools, in a medium-sized municipality located in the northwest of the State of São Paulo, Brazil, in 2014.

A total of 19 schools participated in the study (out of the 20 elementary schools in the urban area), and one school did not consent to participate in the research during the time available for data collection $(N=4.283)$. The sample consisted of adolescents aged from 11 to 16 years-old, students from 7th, 8th and 9th grade, so that they could answer the self-administered questionnaire. Exclusion criteria were: adolescents whose parents did not authorize the exams, adolescents who had parents' authorization but did not want to participate in the survey, and those who were not present on the three dates scheduled for the exams. The final sample consisted of 815 adolescents (19.03\%).

\section{Ethical aspects}

This study was approved by the Research Ethics Committee under protocol number FOA-01080/2011. The adolescents were examined only when the consent term had been signed by the parents or guardians. The data collection began after the authorization of the regional education leader and the school principals involved in the research.

\section{Data collection}

Initially, the subjects answered the self-administered questionnaire containing the Global Negative Self-Assessment scale to identify the level of self-esteem and the Kidscape questionnaire to assess bullying.

The Global Negative Self-Evaluation ${ }^{14}$ instrument consists of a six-item scale, each one presenting six response alternatives, which are quantified in ascending order (1 to 6), following the scale arrangement. Through this instrument, it is possible to classify self-esteem in four categories: 1-1.69, very negative self-assessment; 1.7 - 2.69, low negative selfassessment; 2.7 - 3.99, negative self-assessment; 4.0-6.0, very negative self-assessment. The results were dichotomized in low negative self-esteem (1-2.69) and very negative selfesteem (2.7-6) to facilitate data analysis.

In order to assess bullying among schoolchildren, the research used a British-English instrument named KIDSCAPE which prevents bullying and child sexual abuse ${ }^{15}$. The following questions were considered for this 
evaluation: frequency of bullying, its consequences, the type of intimidation, the sex of the perpetrator and whether the victim, himself, has ever been a bully.

Afterwards, an oral exam was performed following the World Health Organization requirements and using the Dental Aesthetic Index (DAl), an instrument proposed by Cons et al. ${ }^{16}$ which evaluates the individual's aesthetic commitment, besides occlusion. After the examination, the occlusal condition is categorized into: no abnormality or mild malocclusion (no need for treatment), definite malocclusion, severe malocclusion and very severe or disabling malocclusion. For the data analysis, the results of this index were dichotomized as follows: need of treatment (> 25 - mild, moderate and severe) and without need of treatment ( $\leq 25$ - normal).

The oral examination and the questionnaire application were performed in the teaching institution by a previously calibrated single researcher and specialist in orthodontics. The calibration of the team (examiner and note-taker) and the methodological adjustments were made in the pilot study preceding the research. In this stage, 26 participants were examined within 15 days and excluded from the final sample. Intra-examiner diagnostic agreement was measured by the kappa statistical test and considered optimal (kappa $=0.91)$.

\section{Data analysis}

Data were analyzed using the SAS for Windows, version 9.3. The chi-square test or Fisher's test was used at a $5 \%$ level of significance in order to verify the association between self-esteem (negative and very negative) with the following variables: gender, age, skin color, desire to correct their teeth, bullying, frequency with which they have been bullied, sex of perpetrator, type of bullying suffered and whether the victim has already been a bully. The multivariate analysis was performed through logistic regression considering self-esteem as a response variable and the others as explanatory. The variables which presented statistical significance were introduced into the model and the results were expressed as odds ratio (OR) in the association with very negative self-esteem and the respective 95\% confidence interval (CI).

\section{RESULTS}

A total of 4.283 applications for authorization were submitted, with a return rate of $19.03 \%$, totaling 815 adolescents participating. The minimum sample size was 384 individuals, considering that, for the age group of students, the prevalence of bullying in the city of Araçatuba, State of São Paulo is unknown (50\%), with a $5 \%$ margin of error and $95 \%$. Regarding all the schools in the municipality, the data collection was performed in two stages: one that took into consideration the schools and the other, the students. Thus, it can be stated that there is an effect of the sampling design of two (referring to 2 collection stages). The sample size was of at least 768 individuals, which could already be seen as representative but in fact 815 students were examined in all, therefore the sample can be considered representative, besides the bullying estimate in the sample was $48.22 \%$, which is close to the established prevalence and within the margin of error considered.

Table 1 presents the descriptive results of the study containing the following variables: age, sex, skin color, DAl index, Global Negative Self-Evaluation and desire to correct teeth in order to improve appearance. The result descriptive analysis of the bullying questionnaire is shown in Table 2.

Table 1. Variable distribution: age, sex, skin color, Dental Aesthetic Index, Global Negative Self-Evaluation scale and the desire to straighten teeth in order to improve appearance. Adolescents enrolled in municipal schools in the city of Araçatuba, State of São Paulo (SP), 2014

\begin{tabular}{|c|c|c|}
\hline VARIABLES & $\mathbf{n}$ & $\%$ \\
\hline \multicolumn{3}{|l|}{ Age } \\
\hline 11 & 14 & 1.72 \\
\hline 12 & 254 & 31.17 \\
\hline 13 & 225 & 27.61 \\
\hline 14 & 259 & 31.78 \\
\hline 15 & 55 & 6.75 \\
\hline 16 & 8 & 0.98 \\
\hline \multicolumn{3}{|l|}{ Sex } \\
\hline Female & 488 & 59.88 \\
\hline Male & 327 & 40.12 \\
\hline \multicolumn{3}{|l|}{ Skin color } \\
\hline White & 333 & 40.86 \\
\hline Black & 97 & 11.90 \\
\hline Mulatto & 385 & 47.24 \\
\hline \multicolumn{3}{|l|}{ Dental Aesthetic Index } \\
\hline$\leq 25$ (No abnormality or light Malocclusion) & 491 & 60.24 \\
\hline 26-30 (Defined Malocclusion) & 179 & 21.96 \\
\hline 30-35 (Severe Malocclusion) & 78 & 9.58 \\
\hline$\geq 36$ (Very severe Malocclusion ) & 67 & 8.22 \\
\hline \multicolumn{3}{|l|}{ Global Negative Self-Evaluation } \\
\hline $1.00-1.69$ very low negative & 241 & 29.57 \\
\hline 1.70-2.69 low negative & 256 & 31.41 \\
\hline 2.70-3.99-Negative & 223 & 27.36 \\
\hline 4.00-6.00- very low negative & 95 & 11.66 \\
\hline \multicolumn{3}{|l|}{$\begin{array}{l}\text { Desire to straighten teeth to improve } \\
\text { appearance }\end{array}$} \\
\hline Yes & 745 & 91.41 \\
\hline No & 10 & 59 \\
\hline
\end{tabular}


Table 2. Absolute and perceptual variable distribution related to bullying episodes in adolescentes enrolled in public schools in the city of Araçatuba. Araçatuba (SP), 2014.

\begin{tabular}{|c|c|c|}
\hline VARIABLES & $\mathbf{n}$ & $\%$ \\
\hline \multicolumn{3}{|l|}{ Bullying victim } \\
\hline Yes & 393 & 48.22 \\
\hline No & 422 & 51.78 \\
\hline \multicolumn{3}{|l|}{ Bullying Frequency } \\
\hline Once & 137 & 34.86 \\
\hline Many times & 161 & 40.97 \\
\hline Almost every day & 57 & 14.50 \\
\hline Several times a day & 38 & 9.67 \\
\hline \multicolumn{3}{|l|}{ Bullying consequences } \\
\hline No consequences & 214 & 54.44 \\
\hline Some bad consequences & 140 & 35.61 \\
\hline Terrible consequences & 22 & 5.96 \\
\hline Had to move to another school & 17 & 4.31 \\
\hline \multicolumn{3}{|l|}{ Perpetrator's sex } \\
\hline Boy & 256 & 65.14 \\
\hline Girl & 91 & 23.16 \\
\hline Boy and Girl & 44 & 11.20 \\
\hline No answer & 2 & 0.51 \\
\hline \multicolumn{3}{|l|}{ Type of bullying } \\
\hline Emotional & 36 & 9.17 \\
\hline Verbal & 183 & 46.56 \\
\hline Physical & 55 & 14.00 \\
\hline Racist & 48 & 12.21 \\
\hline Sexual & 11 & 2.80 \\
\hline More than one answer & 58 & 14.80 \\
\hline No answer & 2 & 0.21 \\
\hline \multicolumn{3}{|l|}{ Bullying perpetrator } \\
\hline Yes & 127 & 32.31 \\
\hline No & 266 & 67.69 \\
\hline
\end{tabular}

Table 3 shows the relationship between low negative self-esteem and very negative self-esteem with the other variables. It was observed that there was no statistically significant association between the variables age range, need for orthodontic treatment, sex of the aggressor, type of bullying suffered and whether the victim had previously been a bully.

The variables which showed significant associations were dichotomized to allow multivariate logistic regression analysis. The frequency with which the bullying occurred was categorized as follows: one episode and more than one episode. Regarding bullying consequences, they were categorized as with and without consequences. Although the following variables: sex, desire to correct the teeth in order to improve the appearance and the bullying episode frequency seen as a risk factor for very negative self-esteem victims, these variables were not significant. The items: Non-white adolescents and bullying with consequences had a significant effect on the occurrence of intimadation (Table 4).
Table 3. Self- esteem association with other variables. Araçatuba (SP), 2014.

\begin{tabular}{|c|c|c|c|}
\hline VARIABLES & $\begin{array}{c}\text { Very low } \\
\text { self- } \\
\text { esteem } \\
n(\%)\end{array}$ & $\begin{array}{l}\text { Low self- } \\
\text { esteem } \\
\text { n (\%) }\end{array}$ & P VALUE \\
\hline \multicolumn{4}{|l|}{ Sex } \\
\hline Female & $218(26.75)$ & $270(33.13)$ & \multirow{2}{*}{$<.0001$ * } \\
\hline Male & $100(12.27)$ & $227(27.85)$ & \\
\hline \multicolumn{4}{|l|}{ Age group } \\
\hline $11-13$ & $195(23.93)$ & $298(36.56)$ & \multirow{2}{*}{0,6983} \\
\hline $14-16$ & $123(15.09)$ & $199(24.42)$ & \\
\hline \multicolumn{4}{|l|}{ Skin color } \\
\hline White & $110(13.50)$ & $223(27.36)$ & \multirow{3}{*}{0.0131} \\
\hline Mulatto & $40(4.91)$ & $57(6.99)$ & \\
\hline Black & $168(20.61)$ & $217(26.63)$ & \\
\hline \multicolumn{4}{|l|}{ Dental Aesthetic Index } \\
\hline$\leq 25$ (no treatment need) & $185(22.70)$ & $306(37.55)$ & \multirow{2}{*}{0.3343} \\
\hline >25 (treatment need) & $133(16.32)$ & $191(23.44)$ & \\
\hline \multicolumn{4}{|l|}{ Desire to straigthen teeth } \\
\hline Yes & $304(37.30)$ & $441(54.11)$ & \multirow{2}{*}{$0.0006^{*}$} \\
\hline No & $14(1.72)$ & $56(6.87)$ & \\
\hline \multicolumn{4}{|l|}{ Bullying victim } \\
\hline Yes & $203(24.91)$ & $190(23.31)$ & \multirow{2}{*}{$<.0001$ * } \\
\hline No & $115(14.11)$ & 307 (37.67) & \\
\hline \multicolumn{4}{|l|}{ Bullying frequency } \\
\hline Once & $60(15.27)$ & $77(19.59)$ & \multirow{4}{*}{$0.0111 *$} \\
\hline Several times & $81(20.61)$ & $80(20.36)$ & \\
\hline Almost every day & $39(9.92)$ & $18(4.58)$ & \\
\hline Several times a day & $23(5.85)$ & $15(3.82)$ & \\
\hline \multicolumn{4}{|l|}{ Bullying consequences } \\
\hline No Consequences & $82(20.87)$ & $132(33.59)$ & \multirow{4}{*}{$<.0001^{\star}$} \\
\hline Some bad consequences & $94(23.94)$ & $46(11.70)$ & \\
\hline Very bad consequences & $16(4.07)$ & $6(1.53)$ & \\
\hline $\begin{array}{l}\text { Had to move to another } \\
\text { school }\end{array}$ & $11(2.80)$ & $6(1.53)$ & \\
\hline \multicolumn{4}{|l|}{ perpetrator 'sex } \\
\hline Boy & $128(32.57)$ & $128(32.57)$ & \multirow{4}{*}{0.0600} \\
\hline Girl & $45(11.45)$ & $46(11.70)$ & \\
\hline Boy and girl & $30(7.63)$ & $14(3.56)$ & \\
\hline Did not answer & - & $2(0.51)$ & \\
\hline \multicolumn{4}{|l|}{ Type of bullying } \\
\hline Emotional & $18(4.58)$ & $18(4.58)$ & \multirow{7}{*}{0.1579} \\
\hline Verbal & $85(21.6)$ & $5(1.27)$ & \\
\hline Physical & $28(7.12)$ & $27(6.87)$ & \\
\hline Racist & $26(6.62)$ & $22(5.60)$ & \\
\hline Sexual & $5(1.27)$ & $6(1.53)$ & \\
\hline More than one answer & $40(10.18)$ & $18(4.58)$ & \\
\hline Did not answer & $1(0.25)$ & $1(0.25)$ & \\
\hline \multicolumn{4}{|l|}{$\begin{array}{l}\text { Victim has been a bullying } \\
\text { perpetrator }\end{array}$} \\
\hline Yes & $68(17.30)$ & $59(15.0)$ & \multirow{2}{*}{0.6045} \\
\hline No & $135(34.35)$ & $131(33.33)$ & \\
\hline
\end{tabular}

Note: *statistically significant 
Table 3. Self- esteem association with other variables. Araçatuba (SP), 2014.

\begin{tabular}{|c|c|c|c|}
\hline VARIABLES & & OR & IC $95 \%$ \\
\hline \multirow[t]{2}{*}{ Sex } & Female & 1.326 & $0.856-2.055$ \\
\hline & Male & 1 & \\
\hline Skin color & $\begin{array}{c}\text { Non white } \\
\text { white }\end{array}$ & $\begin{array}{c}1.914 \\
1\end{array}$ & $1.239-2.956^{*}$ \\
\hline Desire to straighten teeth & $\begin{array}{l}\text { Yes } \\
\text { No }\end{array}$ & $\begin{array}{c}1.805 \\
1\end{array}$ & $0.756-4.307$ \\
\hline Bullying frequency & $\begin{array}{c}\text { Once } \\
\text { More than } \\
\text { once }\end{array}$ & $\begin{array}{c}1.202 \\
1\end{array}$ & $0.763-1.893$ \\
\hline Bullying consequences & $\begin{array}{c}\text { With } \\
\text { consequences } \\
\text { Without } \\
\text { consequences }\end{array}$ & $\begin{array}{c}3.343 \\
1\end{array}$ & $2.152-5.192^{*}$ \\
\hline
\end{tabular}

Note: *statistically significant

\section{DISCUSSION}

The profile of the students surveyed reveals a great deal of female students, with a slight predominance of brown skin color and age showing a balanced distribution among the participants.

In 2010, data from the last census in the municipality, comprising the age group of 5 to 9 years old and 10 to 14 years old, revealed that there is no female predominance whereas in the age group of 5 to 9 years old, the proportion of boys and girls was the same (2.9\%) and, in the group of 10-14 years old, there was a small advantage in the percentage of boys when compared to girls $(3.7 \% \text { and } 3.4 \% \text {, respectively })^{17}$.

The fact that more girls participated in the study may be related to the greater interest of female adolescents in participating in this type of research. This variable had a statistically significant association in the chi-square test and could be considered a risk factor for victims of bullying presenting a very negative self-esteem, although it did not present significance in the logistic regression model.

A possible explanation for this finding is the difference between the factors that influence the selfesteem of girls and boys. Girls are more influenced by issues related to relationships, while boys, by the success achieved in their goals. During adolescence, girls may overestimate the opinion of friends and people they consider important; Thus, criticisms of these relationships over their image are significant ${ }^{6}$. Thus, it can be concluded that the fact that the girls suffer from bullying, that is, the rejection of the peers, negatively influences the level of their self-esteem

Although it was not the majority of adolescents who reported poor levels of self-esteem, there was a high percentage of those who reported having very negative selfesteem (39.02\%). This information is of great importance because the low level of self-esteem may be related to the prevalence of behavioral and emotional disorders, as well as to antisocial behaviors (aggression / violence, criminal activities, suicidal thoughts, smoking, illicit drug use and low school performance) ${ }^{18}$.

The results showed a high rate of bullying (48.22\%). The students were previously instructed to complete the questionnaire about what characterized bullying episodes in order to find out how to differentiate them from games between colleagues. Nevertheless, the prevalence was higher than other similar studies ${ }^{19-20}$. This fact can be justified by the methodological differences employed as well as the cultural differences. In addition, in the present study, there was no temporal limitation, that is, the student was questioned about episodes of bullying in any period prior to the research, thus increasing the chances of detecting more reports. It is essential to emphasize that, even though it is not the objective of the research, situations of violence in the school regions are frequently reported in the local media, which could justify the high percentage of young people involved in bullying episodes.

The majority of adolescents reported having experienced this type of situation more than once. Although it may have happened once, the main characteristic of this type of violence is the fact that the victim is persecuted by his tormentors ${ }^{21}$. The results also showed that the most common intimidation was verbal and that the perpetrators, most of the times, were boys. These data are commonly found in other studies on this theme in different regions and countries at all levels of development ${ }^{4,19-23}$.

The literature reports that episodes of bullying are strongly related to low levels of self-esteem among adolescents ${ }^{21-22,24}$. Likewise, the present study found a statistically significant association between the victims of bullying and the level of self-esteem. In the logistic regression model, it can be observed that those who suffered bullying as well as non-white adolescents were twice as much prone to present very negative self-esteem. Data released by the National School Health Survey (NSHS), conducted by IBGE in partnership with the Ministry of Health in 2012, also showed a greater chance of black boys being the most victims of bullying ${ }^{25}$. 
Brazil is a great miscegenation country, yet certain cultural and socially valued patterns and stereotypes still prevail. Often, these stereotypes are distant from those found in most of the population. Some of the characteristics most valued concerning the appearance are: white skin, straight and blond hair and lean body. It is necessary, therefore, to think about the differences, since the motivation for the practice of bullying comes precisely from the differences, that is, from those who differ from socially valued standards ${ }^{26}$. Racial prejudice is present in all sectors, as well as in the school environment, which can negatively affect the self-esteem of bullying victims.

Bullying consequences in adolescents' lives directly affect very negative self-esteem (odds ratio $=3.343$ ). There are situations in which self-esteem may be so compromised that the victim believes that he or she deserves the violence suffered ${ }^{24,27-28}$. Some of the characteristics commonly found in these young people are: social withdrawal, few friends, insecurity, lack of hope regarding the group adjustment, passiveness, withdrawn, unhappiness, shame, fear, depression and anxiety ${ }^{28-29}$. Moreover, the consequences of these episodes in childhood can have adulthood repercussions associated with antisocial behavior and loss of opportunities, such as job instability and short-term affective relationships ${ }^{27,29}$.

Concerning the association between self-esteem and the need for orthodontic treatment, although it was statistically insignificant, it was observed that a large proportion of adolescents evaluated dental care needs related to malocclusion problems. Moreover, it is worth mentioning that, regardless of the need for orthodontic treatment, almost all the participants (91.41\%) showed a desire to correct their teeth in order to improve their appearance. This variable can be considered as a risk factor (odds ratio $=1.805$ ) represented as a very negative selfesteem for victims of bullying, showing an expressive 0 adolescents' concern with their dental appearance.

Bullying can affect the physical and mental health of adolescents, requiring the attention of schools,

\section{REFERENCES}

1. Cavalcanti AL. Maxillo facial injuries in victims of violence at school environment. Ciênc Saúde Coletiva. 2009;14(5):1835-42. doi: 10.1590/S1413-81232009000500025

2. Olweus D. Bullying at school: basic facts and effects of a school based intervention program. J Child Psychol Psychiatry. 1994;35:1171-90. doi: 10.1111/j.1469-7610.1994.tb01229.x parents and the community. The present study detected high levels of very negative self-esteem and bullying among schoolchildren, bringing different consequences in adulthood. Thus, it is necessary to identify the risk factors so that adequate preventive actions can be developed.

\section{CONCLUSIONS}

It was concluded that there was an association between the variables self-esteem and bullying. Those who reported negative consequences on bullying were three times more likely to have very negative self-esteem, and the chances of non-white adolescents were almost twice as high. There was no statistically significant association between self-esteem and need for orthodontic treatment. Although these findings cannot be generalized to other localities, it is of great importance to understand the reality of different regions, to map this serious public health problem and thus create prevention strategies. In addition, further studies should be conducted using different methodological approaches such as qualitative analysis in order to better understand the feelings of adolescents involved in bullying episodes and longitudinal studies to verify the consequences of these episodes in adult life.

\section{Collaborators}

RCJ GATTO, performed the bibliographic survey, data collection and the writing of the article. AJl GARBIN, participated in the design of the project and collaborated with the critical review relevant intellectual content. CAS GARBIN, collaborated in the conception of the project, guided the bibliographic survey, data collection and participated in the writing of the article, final editing and correction. JE CORRENTE, conducted data analysis.

\section{Acknowledgment}

The CNPQ by granting doctoral scholarship.

3. Fekkes M, Pijpers Fl, Verloove-Vanhorick SP. Effects of antibullying school program on bullying and health complaints. Arch Pediatr Adolesc Med. 2006;160(6):638-44. doi: 10.1001/ archpedi.160.6.638

4. Kowalski RM, Limber SP. Psychological, physical, and academic correlates of cyberbullying and traditional bullying. J Adolesc Health. 2013;53:S13-20. doi: 10.1016/j.jadohealth.2012.09.018

5. Malta DC, Silva MAI, Mello FCM, Monteiro RA, Sardinha LMV, Crespo $C$, et al. Bullying in Brazilian schools: results from the 
National School-based Health Survey (PeNSE), 2009. Ciênc Saúde Coletiva. 2010;15:3065-76. doi: 10.1590/S141381232010000800011

6. Bandeira, CM, Hutz CS. Implications of bullying in adolescents' self-esteem. Psicol Esc Educ. 2010;14:131-8. doi: 10.1590/ S1413-85572010000100014

7. Costa ACG. Protagonismo juvenil: adolescência, educação e participação democrática. Salvador: Fundação Odebrecht; 2000.

8. Campos FL, Vazquez FL, Cortellazzi KL, Guerra LM, Ambrosano $\mathrm{GMB}$, Meneghim MC, et al. A má oclusão e sua associação com variáveis socioeconômicas, hábitos e cuidados em crianças de cinco anos de idade. Rev Odontol UNESP. 2013;42:160-6.

9. Borges CM, Peres MA, Peres, KG. Associação entre presença de oclusopatias e insatisfação com a aparência dos dentes e gengivas: estudo com adolescentes brasileiros. Rev Bras Epidemiol. 2010;13(4):713-23. doi: 10.1590/S1415-790X2010000400015

10. Carvalho FS de, Carvalho CAP de, Sales-Peres A, Bastos JR de $\mathrm{M}$, Sales-Peres SH de C. Epidemiology of malocclusion in children and adolescents: a critic review. RGO, Rev Gaúch Odontol. 2014;62(3):253-60. doi: 10.1590/19818637201400030000041190

11. Shaw WC, Meek SC, Jones DS. Nicknames, teasing, harassment and the salience of dental features among school school children. Br Dent J. 1980,7:75-80.

12. Morais $\mathrm{CH}$ de, Zanin $\mathrm{L}$, Degan $\mathrm{V}$, Valdrighi HC, Venezian $\mathrm{CC}$, Vedovello SAS. Malocclusion in schoolhildren aged $7-12$ years old in Minas Gerais, Brazil. RGO, Rev Gaúch Odontol. 2016:64(2):16470. doi: 10.1590/1981-863720160002000062970

13. Helm S, Petersen PE, Kreiborg S, Solow B. Effect of separate malocclusion traits on concern for dental appearance. Community Dent Oral Epidemiol. 1986;14:217-20.

14. Alsaker F, Olweus D. Global self-evaluations and perceived instability of self in Norwegian preschoolchildren and schoolchildren. J Early Adolesc 1986;6:269-78. doi: 10.1111/ j.1467-9450.1993.tb01100.x

15. Kidscape: preventing bullying, protectin children [cited 20 Maio 2015]. Available from: <http://www.kidscape.org.uk>.

16. Cons NC, Jenny J, Kohout FJ, Songpaisan Y, Jotikastira D. Utility of the dental aesthetic index in industrialized and developing countries. J Pub Health Dent. 1989;49:163-6. doi: 10.1111/ j.1752-7325.1989.tb02054.x

17. Instituto Brasileiro de geografia e estatística (IBGE). Censo Brasil 2010 [cited 15 Abr 2015]. Available from: http://www. censo2010.ibge.gov.br/sinopse/webservice/frm_piramide. php?codigo $=350280$
18. Khajehdaluee M, Zavar A, Alidoust M, Pourandi R. The relation of self-esteem and illegal drug usage in high school students. Iran Red Cres Med J. 2013;15:e7682. doi: 10.5812/ircmj.7682

19. Liang $H$, Flisher AJ, Lombard CJ. Bullying, violence, and risk behavior in South African school students. Child Abuse Negl. 2007;31:161-71. doi: 10.1016/j.chiabu.2006.08.007

20. Nansel TR, Overpeck M, Pilla RS, Ruan WJ, Simons-Morton B, Scheidt P. Bullying behaviors among US youth: prevalence and association with psychosocial adjustment. JAMA 2001:285:2094-100.

21. Aalsma MC, Brown JR. What is bullying? J Adolesc Health. 2008;43:101-2. doi: 10.1016/j.jadohealth.2008.06.001

22. Seals D, Young J. Bullying and victimization: prevalence and relationship to gender, grade level, ethnicity, self-esteem, and depression. Adolescence. 2003;38:735-47.

23. Rech RR, Halpern R, Tedesco A, Santos DF. Prevalence and characteristics of victims and perpetrators of bullying. J Pediatr (Rio J). 2013;89:164-70. doi: 10.1016/j.jped.2013.03.006

24. O'Moore M, Kirkham C. Self-esteem and its relationship to bullying behaviour. Aggress Behav. 2001;27:269-83. doi: 10.1002/ab.1010

25. Malta DC, Porto DL, Crespo CD, Silva MMA, de Andrade SSC, Mello, FCM, et al. Bullying em escolares brasileiros: análise da Pesquisa Nacional de Saúde do Escolar (PeNSE 2012). Rev Bras Epidemiol. 2014;17(1):92-105

26. Batista EHM. Bullying and ethnic-racial prejudice. POIÉSIS 2013;7:302-23.

27. Pearce JB, Thompson AC. Practical approaches to reduce the impact of bullying. Arch Dis Child. 1998;79:528-31. doi: 10.1136/adc.79.6.528

28. Ravens-Sieberer $U$, Kökönyei $G$, Thomas $C$. School and health. In: Currie C, Roberts C, Morgan A, Smith R, Settertobulte W Samdal O, et al, editors. Young people's health in context: Health Behavior in School-aged Children (HBSC) study: international report from the 2001/2002 survey. Geneva: World Health Organization; 2004. p. 184-95.

29. Lopes Neto AA. Bullying: aggressive behavior among students. J Pediatr (Rio J). 2005:81:S164-72. doi: 10.1590/S002175572005000700006 